\title{
REPRESENTAÇÕES LUSAS NA AMAZÔNIA BRASILEIRA: PAISAGENS, IMAGENS E TOPÔNIMOS
}

- ELIS DE ARAÚJO MIRANDA *

TAMARA TANIA COHEN EGLER ${ }^{* *}$

Resumo: 0 estudo analisa as representações lusas impressas na paisagem de Cametá, no estado do Pará. Objetiva identificar as referências temporais e sociais dos objetos geográficos, assim como seus significados e intencionalidades. A análise recairá sobre a paisagem atual da cidade, sendo a fotografia o suporte do registro imagético. Por meio de oito imagens que foram feitas em Cametá nos anos de 2004 e 2005, destacam-se elementos considerados significativos para os estudos sobre representações. Os objetos destacados estão relacionados: a) às referências da cultura de uma cidade ribeirinha na Amazônia; b) ao período pombalino (17501777); c) à história, como o movimento da cabanagem (1835-1837); e, d) às referências lusas.

Paravras-chave: representações; Amazônia; imagens e paisagem.

Introdução

O estudo analisa as representações lusas impressas na paisagem de Cametá, no Estado do Pará. Objetiva identificar as referências temporais e sociais dos objetos geográficos, assim como seus significados e intencionalidades.

A análise recairá sobre a paisagem atual da cidade, sendo a fotografia o suporte do registro imagético. Por meio de oito imagens que foram feitas em Cametá nos anos de 2004 e $2005^{1}$ destacam-se elementos considerados significativos para um estudo sobre representações. Os objetos destacados estão relacionados: a) às referências da cultura de uma cidade ribeirinha na Amazônia; b) ao período pombalino $(1750-1777) ; \quad$ c) às referências históricas, como o movimento da Cabanagem (1835-1837); e, d) às referências lusas.

Entende-se que a paisagem da cidade pode ser lida como um texto (DUNCAN, 
1990), por meio dos objetos e símbolos que marcam tempos, grupos sociais, personalidades e fatos históricos. A partir da análise da paisagem como texto a ser lido, analisado e interpretado, é possível desvendar o poder simbólico (BOURDIEU, 1989) dos objetos nela inseridos, provavelmente por representantes de grupos sociais dominantes, transformados em representações coletivas (DURKHEIM, 1978) e aceitos como parte integrante da cultura local (GEERTZ, 1989).

\section{Sobre a paisagem da cidade}

A cidade de Cametá, localizada na margem direita do rio Tocantins, no Estado do Pará, na região amazônica brasileira, tem sua origem na aldeia indígena caamutá-tapera, dos índios camutá. Com o interesse português renovado, após a expulsão dos franceses, em 1515, que haviam fundado a cidade de São Luís, no Maranhão, em 1512, a coroa portuguesa autorizou a fundação de vilas e cidades onde quer que fosse necessário para assegurar a posse do vasto território desconhecido. Nesse contexto foi fundada a Vila Viçosa de Santa Cruz do Camutá, no ano de $1635^{2}$.

Até 1753 a Vila Viçosa não passava de um aldeamento. A partir desta data sucedem-se as "resoluções régias" "que aprova o ajuste relativo às capitanias brasileiras da Paraíba do Sul, do Visconde de Asseca e a do ArmeiroMor, e a de Cumá e Camutá, de Francisco
Coelho de Carvalho" (SALDANHA, 2001, p. 422), devolvendo ao Estado português o domínio dessas terras. Assim, Camutá passa a fazer parte da área de intervenção territorial e urbanística portuguesa executada pelo Marquês de Pombal.

A partir da intervenção pombalina a Vila teve sua paisagem transformada. Foi implementada a primeira intervenção urbanística e passou a ter traçado urbano, com ruas e praças bem delimitadas, prédios públicos projetados para abrigar os poderes locais, como a Igreja de São João Batista, a Casa de Câmara e Cadeia que se mantêm até a atualidade com os principais objetos geográficos construídos no século XVIII.

A história das colônias portuguesas possui um divisor de águas: a política pombalina (1751-1777). Este período recebeu esta denominação como alusão ao Marquês de Pombal, ou Sebastião José de Carvalho e Melo, o todo poderoso Primeiro Ministro de D. José I, rei de Portugal em 1750. Marquês de Pombal pode ser considerado um dos homens mais importantes da história política de Portugal.

Sendo o Brasil uma das colônias de Portugal, foi profundamente marcado pelas ações pombalinas que estavam baseadas em três objetivos gerais: 1) submeter a alta nobreza ao controle da Coroa; 2) fortalecer a qualquer custo os grandes comerciantes portugueses e 3 ) evitar a interferência da Igreja nas decisões da monarquia (SANTOS, 2001). Todas as ações executadas em Portugal e nas colônias tomaram como base esses objetivos. Assim, Pombal 
idealizou e executou nova forma de administração para as colônias de Portugal, o que provocou alterações na formação sócioespacial no Brasil, mas principalmente na Amazônia.

Segundo Machado:

(...) a denominada "política pombalina" supôs uma certa modernização dos princípios de governo e principalmente, no que se refere ao Estado colonial, uma sistematização da política territorial. A execução do Tratado de limites (1750), o estabelecimento da Companhia Geral do Comércio do Grão Pará (1755), a declaração da liberdade dos indígenas da América portuguesa (1758), a expulsão dos jesuítas dos domínios portugueses (1759), são as decisões políticas com maior impacto na bacia Amazônica (MACHADO, 1989, p. 77).

E, segundo Araújo:

(...) Pombal, de facto, personaliza o seu Governo, e neste sentido cabe a noção da existência de um conceito de "pombalismo" (...) Portanto, o que quer que signifique, $\mathrm{o}$ pombalismo tem tanto a ver com Pombal como com o tempo de Pombal e as circunstâncias em que atua (...) (ARAÚJO, 1998, p. 61).

O Tratado, assinado em 1750, foi o Tratado de Madri, por meio do qual era reconhecido o domínio de Portugal sobre as terras situadas a oeste de Tordesilhas. O estabelecimento da Companhia Geral do Comércio do Grão Pará (1755-1775) assegurou aos comerciantes portugueses estabelecidos na Amazônia o monopólio do comércio das drogas do sertão, em substituição aos jesuítas que até então controlavam este comércio. A declaração da liberdade dos indígenas da América portuguesa (1758) objetivava desarticular as missões religiosas que utilizavam a mão-deobra indígena para a coleta das drogas do sertão, e o golpe final foi a expulsão dos jesuítas dos domínios portugueses (1759), já que estes religiosos jesuítas alcançaram um poder, econômico e simbólico, muito maior que a própria coroa portuguesa (MAXWELL, 1996; ARAÚJO, 1998; MACHADO, 1989).

O resultado da ação de Intervenção Urbanística Portuguesa, projetada e executada durante a administração do Marquês de Pombal, sobre o território 
amazônico, foi uma significativa alteração no mapa da região. Até Pombal a ocupação da Amazônia restringia-se à foz do rio Amazonas e mais quatro pontos isolados que controlavam a foz do rio Amazonas. Após a intervenção pombalina o que se viu foi a formação do embrião de uma rede de cidades articulada pelos principais rios da região e o início da penetração do colonizador no interior do território, com a implantação de culturas de cacau e produção de anil, com mão-de-obra de escravos africanos. Todo o comércio dos negros africanos como escravos e os produtos produzidos eram comercializados pela poderosa Companhia Geral do Grão-Pará e Maranhão (1755-1775).

Para por em prática seu projeto intervencionista na Amazônia, Pombal nomeou, para a Província do Grão-Pará, ainda em 1751, seu irmão Francisco Xavier de Mendonça Furtado ao governo e comissário das demarcações do norte. As instruções secretas do Marquês de Pombal ao seu irmão "se referem a questões de mãode-obra, colonização e aspectos territoriais" (MACHADO, 1989, p. 91). Assim, propõe para a Amazônia, a mudança da sede do governo da cidade de São Luís para Belém do Pará e também ordenou o estabelecimento de povoações e missões no Cabo Norte (hoje Estado do Amapá), por meio da construção de uma fortaleza que pudesse prevenir as incursões dos franceses; além de introduzir escravos africanos, de forma a estimular a economia local (MACHADO, 1989).

Após estas medidas de cunho político-administrativo, Marquês de Pombal interferiu na organização espacial da região e na paisagem da Amazônia ao incentivar a fundação e construção de "vilas" e "lugares" onde até então só existiam aldeamentos indígenas e missões religiosas, e deu início ao planejamento urbanístico português, ou seja, transformou a paisagem de vilas e aldeias, impondo uma fisionomia e topônimos das cidades de Portugal.

O estudo de topônimos é parte constituinte da "retórica da paisagem" (DUNCAN, 1990), que não deixa de ser uma forma simbólica de demarcar o domínio sobre um território. Ao nomear as novas vilas e cidades amazônicas com topônimos de cidades portuguesas, Pombal demarca o novo território como parte integrante dos domínios da Coroa Portuguesa. Lembrando que as terras a oeste da Amazônia, segundo o Tratado de Tordesilhas (1494), eram de domínio da Espanha, e o Tratado de Madri, em 1750, legitimou a expansão portuguesa para as terras a oeste do tratado anterior, pois este último Tratado era baseado na ocupação efetiva do território, coisa que o Estado português já praticava com o auxílio das ordens religiosas desde o século XVII (SANTOS, 2001).

Assim, o projeto pombalino foi, para além de criar vilas, para nomeá-las e impor 
suas regras administrativas. Atuou na regulação do desenho urbano das principais vilas, no alinhamento das praças, das ruas e dos edifícios (ARAÚUJO, 1998, p.125).

As marcas do pombalismo foram impressas nas vilas e cidades amazônicas através da operacionalização de uma metodologia de construção de cidades executada por engenheiros militares vindos de Portugal para a Amazônia para colocarem em prática o planejamento urbanístico português (VITERBO, 1922). E, ainda segundo Araújo (1998), existia um padrão de planta para cidades de pequeno porte, outro para cidades de médio porte, e um terceiro padrão, para as cidades de grande porte. É possível que Cametá tenha sido classificada como cidade de médio porte em virtude da sua posição de cidade portuária de grande importância para a economia regional, pois era de Cametá que partiam os barcos com o cacau e a borracha, dois dos principais produtos exportados para a Europa.

Marquês de Pombal não se limitou em multiplicar o número de vilas e cidades, e nem de apenas construir um plano urbanístico, mas se baseava principalmente na "noção da cidadecivilizada" (ARAÚJO, 1998, p. 115) e para isso implementou um projeto de reforma urbana dando uma feição mais "nacionalista" a estes lugares. Para isso, as ações implantadas foram desde a elaboração de plantas das cidades, projetos arquitetônicos dos principais prédios públicos, igrejas, fortificações, praças, monumentos, arruamentos e topônimos das vilas e cidades com nomes iguais a cidades de Portugal; também "fixou populações nas colônias e criou legislação protegendo os casamentos de portugueses com as índias" (MENDONÇA, 1989, p. 11).

O pombalismo teve como marca os projetos do arquiteto italiano Antônio José Landi ${ }^{3}$ que foi responsável pelo projeto da Igreja Matriz de Camutá, a Igreja de São João Batista, cujo desenho fora enviado ao Rei em 1759 e sua construção se deu em 1761 (MENDONÇA, 2003; p. 336-338). Assim, o pombalismo criou em Cametá uma paisagem heterogenética, definida por Corrêa (2003) como sendo aquela paisagem criada por um grupo cultural externo àquele da área onde a cidade foi implantada e do qual a cidade colonial é uma expressão. Consideramos Cametá como exemplo desta modalidade de paisagem por ter tido sua paisagem criada a partir de elementos culturais lusos sem que existisse ali uma sociedade lusa.

A partir de meados do século XVIII as vilas e cidades amazônicas receberam o traçado urbano, até então inexistente na região; bem como prédios públicos e igrejas grandiosas foram construídos seguindo as orientações de engenheiros militares vindos de Portugal para manter o padrão das construções lusas, transformando as paisagens amazônicas em paisagens lusas na Amazônia (MACHADO, 1991). 
As paisagens lusas na Amazônia, aquelas construídas pelo Marquês de Pombal, passaram, com o tempo, a se constituir como uma paisagem luso-amazônica. Mas o que pode significar uma paisagem luso-amazônica em Cametá? Este é um debate que deve se realizar a partir do conceito de paisagem no âmbito da Geografia Cultural, que entende a paisagem como além daquilo que se vê. Paisagem é o resultado da relação entre a natureza e a sociedade; ela é, portanto, dinâmica. Assim, a paisagem lusa construída em Cametá no século XVIII, com o tempo assumiu as feições do grupo ali existente, constituindo uma paisagem luso-amazônica, pois, insistimos em afirmar que o projeto pombalino não se efetivou completamente por existir em Cametá outros grupos sociais, além dos portugueses, que deixaram suas marcas, suas representações, com diferentes significados. Algumas dessas marcas permaneceram, outras não. Representações foram recriadas com sentidos forjados e outros foram apropriados de maneira a negar significados passados.

Considero, dessa maneira, que a paisagem de Cametá deve ser analisada a partir do conjunto das representações, e como tal, não condiz com a realidade social do lugar, o que existe é uma paisagem com referências portuguesas, sem que existisse uma sociedade portuguesa, retomando o diálogo com Corrêa (2003).

Importa ressaltar que a posição de Cametá no contexto amazônico não permitiu que a intervenção urbanística fosse mais incisiva, ficando restrita à construção da igreja de São João Batista (1761) e no traçado da cidade, com suas duas praças: uma da igreja matriz e a outra, mais no interior, de onde se vê a cadeia pública (hoje o prédio da prefeitura). A intervenção urbanística portuguesa foi muito rica em termos de símbolo e rito, e a praça exerceu papel simbólico importante na cidade, além de ser uma das marcas do pombalismo. Para Araújo:

O processo compositivo da forma urbana é o primeiro e mais significativo dado da identificação simbólica ritualística. A praça, usada como matriz geradora do desenho e identificada com o centro da cidade, estabelece uma referência simbólica inequívoca, de contornos arquetípicos, de identificação do "centro do mundo" (...) balizando com os atributos do poder, a carga simbólica do espaço central. Os contornos da praça marcados pelos edifícios mais representativos (a igreja, a câmara, a cadeia e o palácio dos governadores), assumem o papel de envolventes do símbolo que o espaço-praça significa, e ao mesmo tempo incorporam eles próprios o referencial simbólico das 
instituições que representam

(a religião e o Estado)

(ARAÚJO, 1998, p. 41).

Em Cametá também foram construídas duas praças com seus prédios representativos e arruamento padronizado, o que, de acordo com as palavras de Araújo (1998), a presença das praças é um forte indício da intervenção urbanística pombalina. Mas, por que em Cametá foram construídos os símbolos mais significativos do poder do Estado e da igreja? Porque, sem dúvida alguma, esta era uma vila colonial com importante papel na consolidação territorial e o mais importante lugar para se constituir uma mentalidade lusa que estava em implantação por Pombal.

A paisagem da cidade de Cametá foi construída pelo urbanismo português do século XVIII. Ao construir prédios com elementos da arquitetura portuguesa e implantar um traçado urbano nos moldes das cidades lusas, Marquês de Pombal pretendia imprimir nas cidades amazônicas a marca da dominação portuguesa e mostrar para o resto do mundo que o domínio português havia se consolidado em todo o território do Brasil.

A paisagem atual apresenta traços da intervenção do projeto do Marquês de Pombal para a Amazônia (1751-1777); da Cabanagem (1835-1837), movimento popular contra os desmandos da elite portuguesa no Pará; e da época em que contava com o principal porto exportador de cacau e outras "drogas do sertão". Tendo sido dominada por grupos sociais diferenciados em cada um desses períodos, a paisagem de Cametá, ainda hoje, expõe temporalidades, referências as familiais dos grupos dominantes, forte influência da igreja católica - e, consequentemente, da cultura lusa - além de elementos da cultura amazônica.

A exemplo do que afirmou Abreu (1988), ao discutir a memória das cidades, as "permanências existentes na paisagem são muito mais resultado de um longo período de decadência econômica e abandono, que exatamente de um trabalho de preservação ou de restauro de seu patrimônio arquitetônico" (ABREU, 1988, p. 8). Cametá é um exemplo de cidade que manteve parte da sua memória urbanística muito mais pela decadência econômica e empobrecimento que exatamente pela preservação de sua história.

Não podemos deixar de considerar ainda a particularidade da paisagem de Cametá que é a sua natureza. Se for a relação da sociedade com a natureza que faz com que as paisagens sejam elaboradas e que objetos de representação sejam impressos, cada lugar vai apresentar uma particularidade. Em Cametá o diferencial está na moldura - o rio Tocantins e ilhas com uma porção de floresta amazônica - e uma sociedade que se constituiu e se estabeleceu neste sítio mantendo fortes relações econômicas e culturais com o rio e a floresta, como será apresentado adiante nas imagens.

A paisagem, categoria analítica do espaço, pode ser trabalhada a partir da ideia de representação, de dominação e exercício de poder dos grupos sociais. A paisagem do 
presente remete-nos para um tempo passado (LOWENTHAL, 1975), como se estivesse ali até agora para que uma explicação seja dada sobre a elaboração daquela paisagem portuguesa no interior da Amazônia.

Segundo Corrêa (2003) a paisagem tem ocorrência espacial, com limites mais ou menos definidos, constituindo um padrão de ocorrência comum. Ela é fruto da história, da ação humana sobre a paisagem natural, transformando-a em paisagem cultural; onde sua dinâmica e fisionomia são derivadas da ação humana. Ela é, por isso, também campo de leitura sobre a sociedade.

É essa a abordagem que nos interessa: a paisagem como fruto da história, da ação humana, reconhecida como a paisagem cultural, e cultura entendida como elaboração social. Esta definição começou a ser discutida no interior da chamada Nova Geografia Cultural e entende que paisagem é forma e é conteúdo (DUNCAN, 1990); é marca e é matriz (BERQUE, 1998), que há uma conjunção com as ideias elaboradas por Bourdieu (1989) de estrutura estruturante, ou seja, há uma relação dialética explícita na relação sociedade/paisagem e que precisa ser analisada sob um olhar relacional. Por meio da interação da natureza com a sociedade compõe-se esta relação de estrutura/estruturante, elaborando-se uma paisagem que é marca/matriz do grupo social, e que possui forma (objetos) e conteúdo (significados).

Pensar a paisagem é considerá-la não só como aquilo que é visível, mas como forma elaborada, pensada e objetivada por meio das relações sociais, que deixam no espaço elementos que podem identificar temporalidades vividas no lugar. Seus significados, crenças e valores, que são culturais, mas que são também parte das relações de dominação construídas pelos grupos sociais, ou seja, paisagem como representação social, como leitura de uma sociedade, como propôs os autores da Nova Geografia Cultural, orienta o nosso olhar sobre a paisagem de Cametá.

Não existindo unanimidade para o conceito de cultura, aceitamos aquela trabalhada por Geertz (1989) em obra clássica sobre a interpretação das culturas. O autor propõe duas ideias sobre cultura. A primeira delas é a de que a cultura é melhor compreendida quando considerada não como complexos de padrões concretos de comportamento - costumes, usos, tradições, feixes de hábitos - como tem sido até agora, mas principalmente como um conjunto de mecanismos de controle - planos, receitas, regras, instruções - para governar o comportamento. A segunda ideia é a de que o homem é precisamente o animal mais desesperadamente preso a tais mecanismos de controle, extragenéticos, fora da pele, a programas culturais, para ordenar seu comportamento. Tal ideia é compartilhada pelos geógrafos que interpretam a paisagem como sistema simbólico.

E Geertz continua a afirmar que a "perspectiva da cultura como 'mecanismo de controle' inicia-se com o pressuposto de que o pensamento humano é basicamente tanto social 
como público - que seu ambiente natural é o pátio familiar, o mercado e a praça da cidade" (GEERTZ, 1989, p. 57). Assim, esse autor ilumina nossas questões sobre a relação existente entre paisagem e cultura. Se cultura é elaboração pensada para o ordenamento de ideias, a paisagem pode ser o veículo de tais elaborações. A leitura da paisagem pode desvendar as referências culturais do lugar, por aquelas referências que estão sendo implementadas no lugar para que seja socialmente assimilado e, com o tempo, possa ser aceito como sendo "parte da cultura local". Assim, a ideia de cultura está relacionada também ao conceito de representação.

Don Mitchell, em diálogo com outros geógrafos da linha da Geografia Cultural, Duncan, Cosgrove e Jackson, discute a ideia de cultura como elaboração, como categoria carregada de significado e expressão de poder simbólico, defende a ideia de que a cultura opera em um mundo dominado pelo poder. Para Mitchell (2008, p. 81),

Em todos os casos, "cultura" é simbólica, ativa, constantemente sujeita a mudanças e marcada por relações de poder. E, em todos os casos, talvez a cultura não seja uma coisa mas sim um processo identificável, uma categoria analítica, um nível ou esfera mapeável. Para os geógrafos culturais, cultura existe [grifo do autor].

A definição de cultura, política cultural e até mesmo de herança cultural deve ser analisada e interpretada como mais um artifício dos produtores dos mecanismos de dominação, como expressão das estruturas sociais de poder. O que nos faz pensar que cada objeto impresso na paisagem pode ser interpretado como objetos de representação, difusores de ideias, carregados de significados e não como objetos símbolos da cultura local e destituída de ideologias.

De acordo com Cosgrove e Jackson:

(...) se a paisagem passa a ser considerada uma imagem cultural, um meio pictórico de representar ou simbolizar tudo o que circunda o ser humano, então pode ser estudada através de vários meios e superfícies: por intermédio da pintura sobre a tela, da escrita sobre o papel, das imagens gravadas em filme, e mesmo da terra, da pedra, da água e da vegetação sobre o solo. Cada um desses meios revela significados que os grupos humanos atribuem às áreas e lugares, e permite relacioná-los temporalmente, bem como pode revelar idéias 
e poderes não explicitados, mas arquitetados pelos produtores

das representações

(COSGROVE E JACKSON, 2000, p. 18).

Assim, neste texto, trabalha-se à luz da teoria das representações (BOURDIEU, 2001) articulada ao método de análise proposto pela Geografia Cultural que orienta a leitura da paisagem, considerada como poder simbólico na sociedade de classes, e que a ideologia se encarrega de se apropriar, por meio da reprodução do espaço de maneira a legitimar e sustentar a dominação de classes. Dessa maneira, o próprio espaço é evocado para articular e reforçar a aceitação e a participação no código cultural da classe dominante.

Assim, iluminado pelas ideias expostas, este trabalho é uma das possibilidades de leitura da paisagem de Cametá, podendo ainda ser ampliado e/ou feito um novo trabalho com outros objetos destacados.

\section{As representações impressas na} paisagem

As representações impressas na paisagem de Cametá serão analisadas a partir de imagens feitas nos anos de 2004 e 2005.
Aceitamos a ideia de que os objetos impressos na paisagem podem ser analisados como ícones da cultura local, representativos de grupos sociais hegemônicos de períodos diferentes da história da cidade e difusores de ideias e significados.

Após a produção das imagens, foi necessário realizar a seleção de quais objetos seriam analisados. Para alguns casos foi preciso fazer montagem de um conjunto de imagens para que se pudesse apresentar a totalidade da paisagem e/ou da representação selecionada. Ressaltamos ainda que a análise não obedece a uma ordem temporal linear, mas busca conduzir o leitor a entrar na cidade como quem chega de barco, desce no cais do porto e, aos poucos, inicia o reconhecimento dos objetos impressos na paisagem, suas temporalidades e as relações sociais explicitadas.

Assim, a primeira imagem analisada diz respeito à paisagem panorâmica da cidade. Para quem chega em Cametá por via fluvial é impossível não sofrer um impacto visual. Após percorrer sete horas de viagem entre Belém (a capital do Estado do Pará) e Cametá, chega-se a esta cidade fundada no século XVII, e depara-se com uma orla que mistura elementos nitidamente amazônicos, como o porto precário e embarcações de vários tamanhos, cores e formas, e que contrasta com aquelas casas de arquitetura portuguesa e uma igreja monumental 


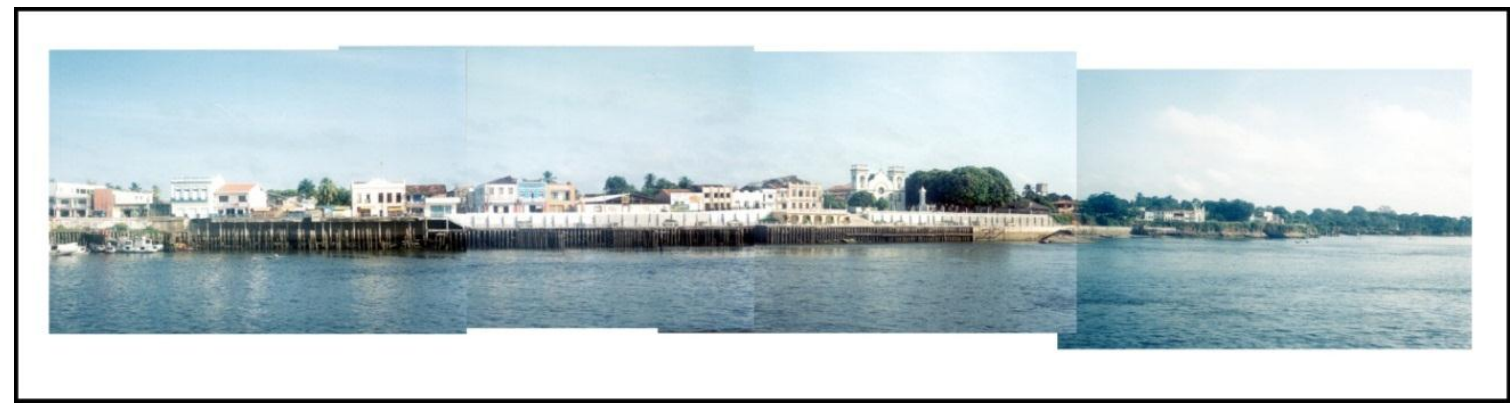

Imagem 1 - Panorâmica de Cametá

Fotos: Elis Miranda (2004)

É possível notar na extremidade direita da fotografia que outra igreja de menor porte quase está sendo afetada pela erosão que assola toda a orla de Cametá. Segundo moradores da cidade, esta pequena igreja fazia parte da propriedade de uma família portuguesa - os Mendes, que descendem da família Lopes Ferreira e dos
Parijós - dona de casas comerciais e de propriedades de plantação de cacau, que para alcançar uma graça prometeu à Nossa Senhora de Nazaré levantar uma igreja em sua homenagem. Com a graça alcançada, o comerciante o fez, mas como a igreja é muito pequena, ficou conhecida como Igreja da Nazarezinha.

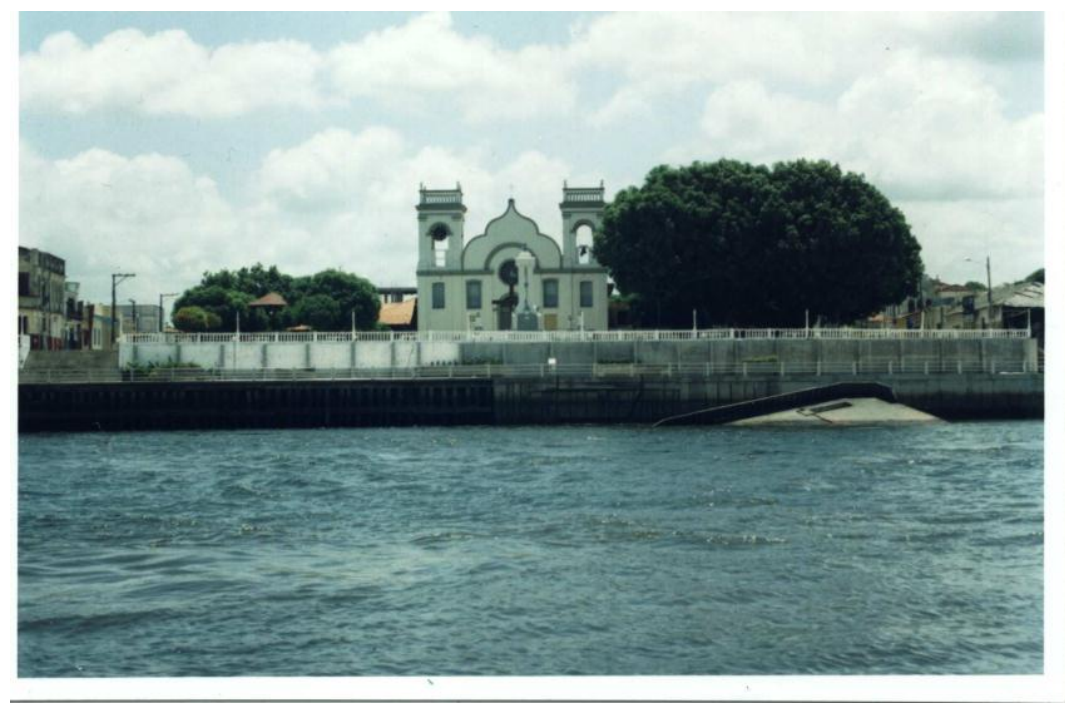

Imagem 2 - Igreja de São João Batista, de 1759

Foto: Elis Miranda (2004) 
A segunda imagem apresenta a Igreja de São João Batista. Erguida na praça central, essa igreja pode ser vista de uma longa distância. Imponente, sua presença na paisagem de Cametá, bem às margens do Tocantins, não deixa dúvida sobre o poder e a riqueza da Igreja católica no século XVIII, que se mantém até hoje. Nessa imagem e na anterior é possível notar que balsas foram fundeadas às margens do rio para proteger a cidade da força das águas. $\mathrm{O}$ trapiche de frente da igreja já foi refeito inúmeras vezes. Uma medida paliativa para que Cametá não perca este ícone da presença lusa em território amazônico.

A terceira imagem refere-se ao monumento erguido na Praça da Prefeitura. $\mathrm{O}$ monumento à Cabanagem (1835-1837) foi construído para lembrar a participação de Cametá na resistência ao movimento popular contra os desmandos da elite portuguesa que vivia em Belém, e fez com que Cametá fosse, temporariamente, capital do Estado do Pará, até que a ordem fosse restabelecida em Belém.

A placa do monumento é assinada por Gerson Perez, o que pode significar a associação do seu nome ao movimento da Cabanagem. Assim, o político pode ser reconhecido como um líder, representante da elite paraense que resistiu à desordem, fato relacionado ao poder simbólico ao qual se refere Bourdieu (1989). A representação simbólica substitui o poder da ação. O que importa é impor-se por meio de um objeto simbólico que marca a história da cidade. Assim, Perez se coloca como um guardião da história, ao mesmo tempo em que se faz lembrar por meio da placa comemorativa. 


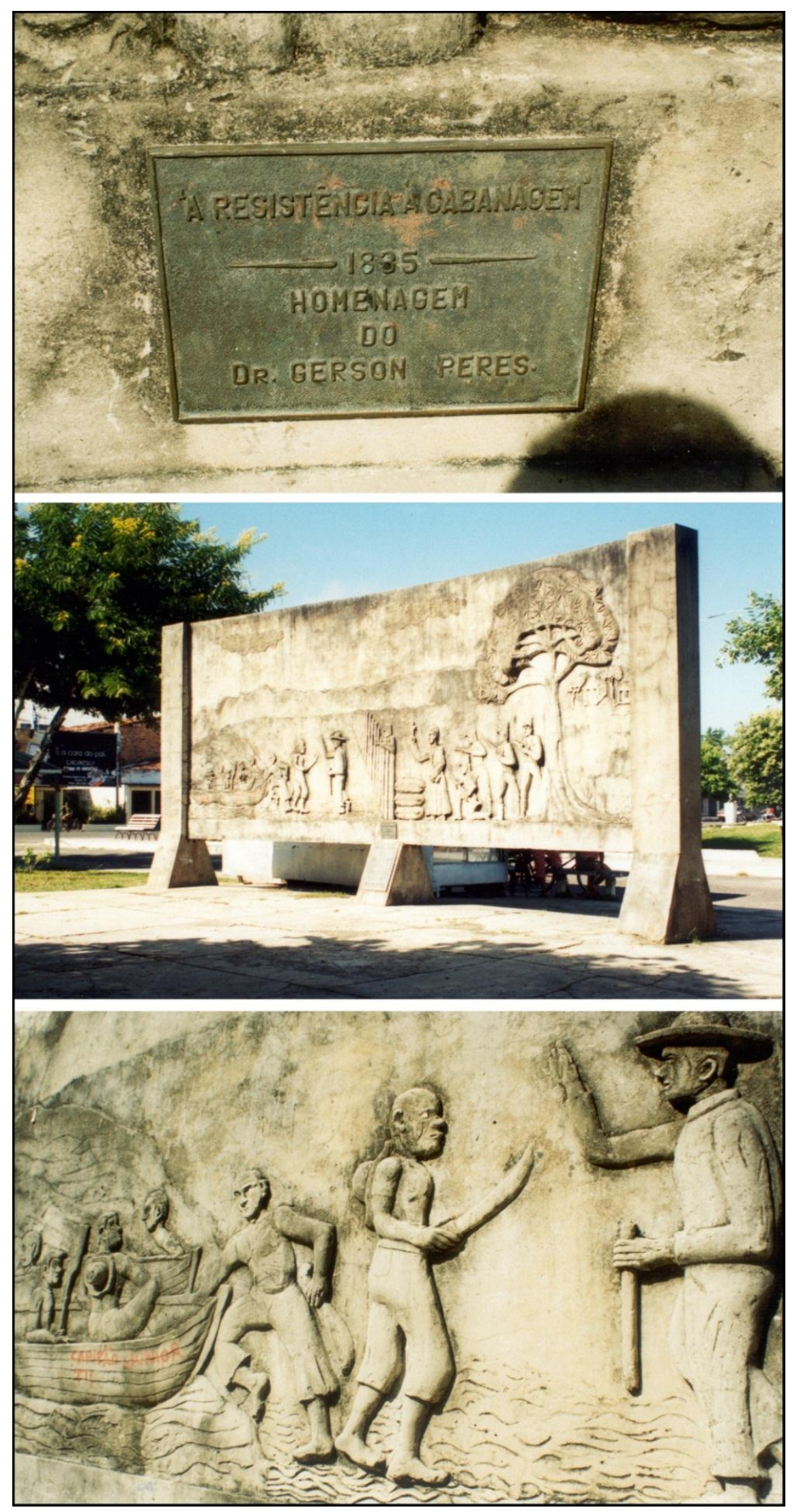

Imagem 3 - Montagem sobre a Cabanagem - "Resistência à Cabanagem"

Fotos: Elis Miranda

ESPAÇO E CULTURA, UERJ, RJ, N. 33, P.149-166, JAN./JUN. DE 2013

http://www.e-publicacoes.uerj.br/index.php/espacoecultura/ 
Destacamos ainda a referência à

herança da cultura portuguesa resistente em Cametá através da arquitetura, ou apenas alguns elementos construtivos, como azulejos, pisos, tipos de portas e janelas. A imagem número cinco mostra uma das casas de Cametá que mantêm os azulejos portugueses na fachada, assim como mantêm um quadro pendurado na fachada que informa ao visitante sobre a construção, seus proprietários, os Perez (os mesmos que ergueram o monumento à Cabanagem).

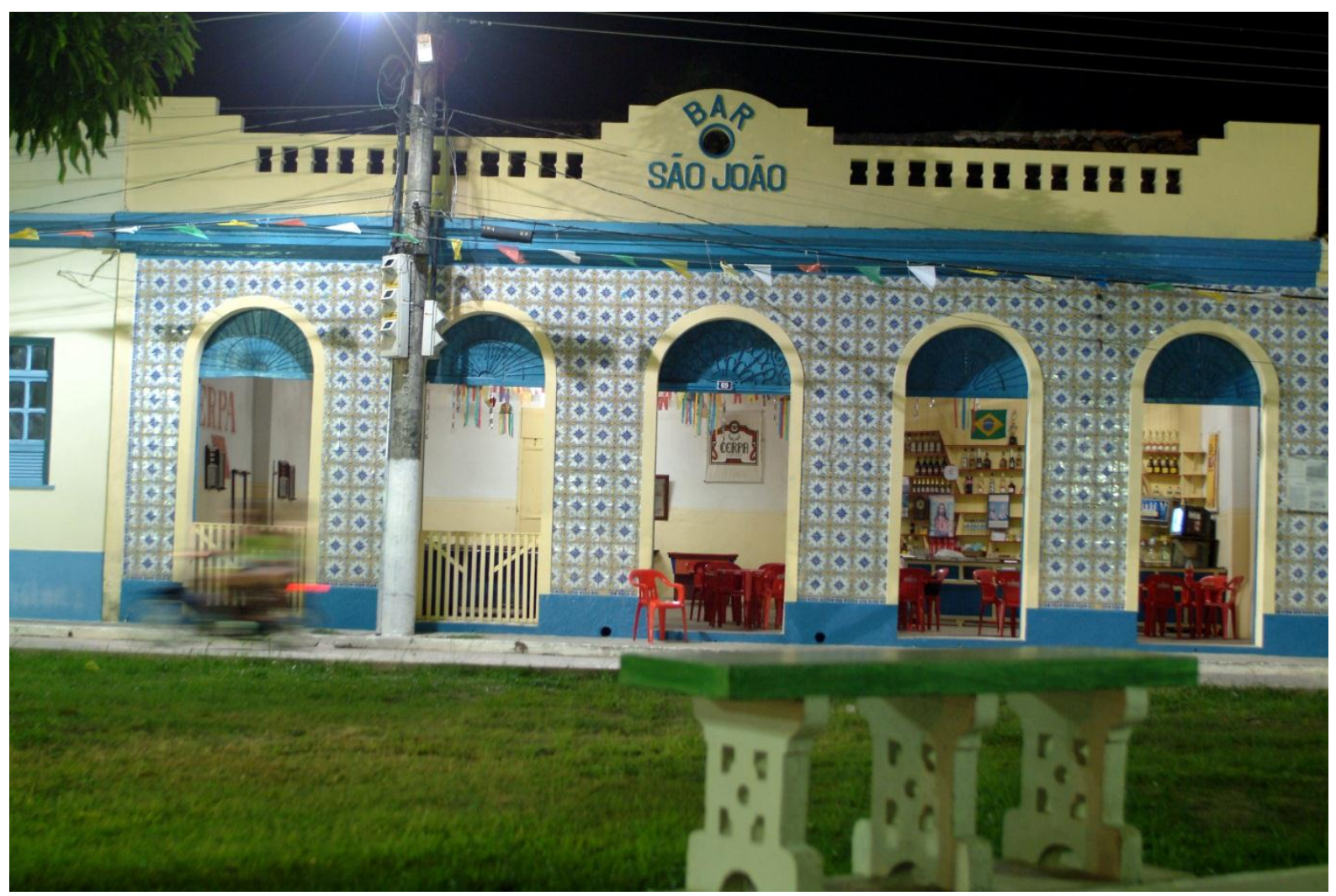

Imagem 4 - Casa de Azulejos Portugueses

Foto: Elis Miranda (2004)

Construída em 1870, esta casa encontra-se localizada na rua ao lado da praça da matriz e da igreja de São João Batista. Pertencia à família mais abastada da cidade, de origem portuguesa. Construir a casa na rua da igreja era um direito das famílias mais abastadas e/ou que faziam parte do grupo de políticos locais.
Além da arquitetura, um hábito luso vivenciado até hoje em Cametá é a sesta. Do meio-dia às três da tarde todo o comércio é fechado, as portas e janelas das residências ficam cerradas e quase não há pessoas a circular pelas ruas. Cametá dorme! Pontualmente às três da tarde recomeçam os trabalhos. Como num segundo amanhecer os 
comerciantes levantam as portas de enrolar e o silêncio dá lugar ao movimento, como até hoje ocorre em algumas cidades de Portugal.

A sétima imagem é uma montagem que destaca os "filhos ilustres" de Cametá, ou como anunciado pelo nome da placa como Praça dos Artistas, que expõe em praça pública a imagem de jornalistas, escritores, músicos e poetas, como em uma demonstração pública da "inteligência cametaense". Além da Praça dos Artistas, existe também a Praça dos Notáveis. Essa apresenta os bustos dos "filhos de Cametá" que se tornaram homens públicos de destaque regional

Ao fazer esta exposição das figuras dos letrados, com nomes, sobrenomes e profissão, afirma-se o poder dos filhos da elite cametaense, que devem ser reconhecidos não só entre os moradores da cidade, mas principalmente pelos forasteiros.

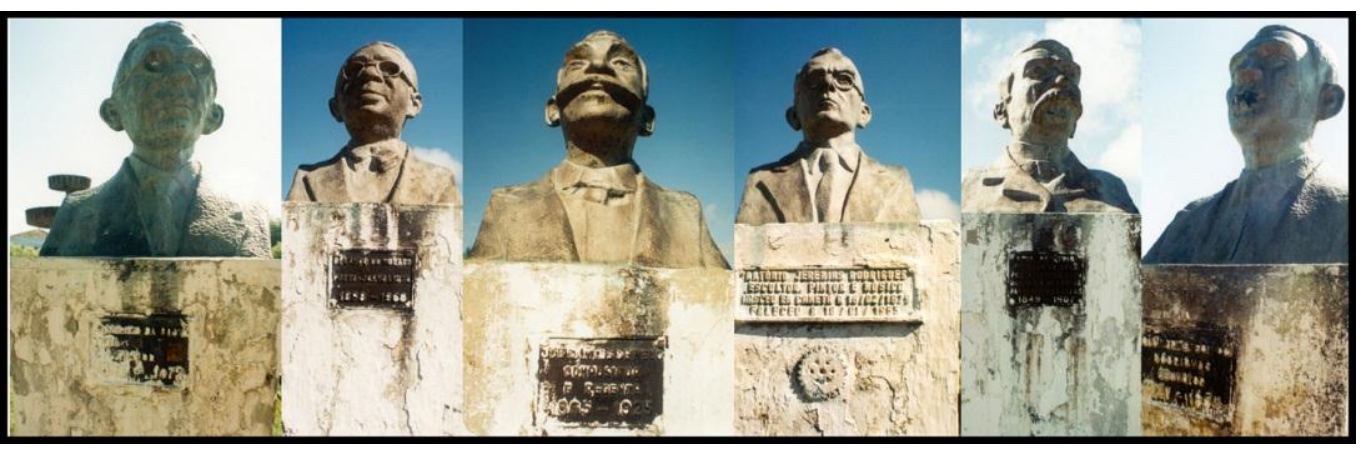

Imagem 5 - Os Artistas

Fotos: Elis Miranda (2004)

A oitava referência diz respeito à igreja se São Benedito. Esta igreja foi construída pelos negros alforriados de Cametá e de vilas próximas. Mesmo alforriados, não era permitido que negros manifestassem sua fé na igreja do padroeiro da cidade - São João Batista. Autorizada pela Igreja católica, a construção de uma igreja só para os negros foi feita em homenagem ao santo preto em 1872 . 


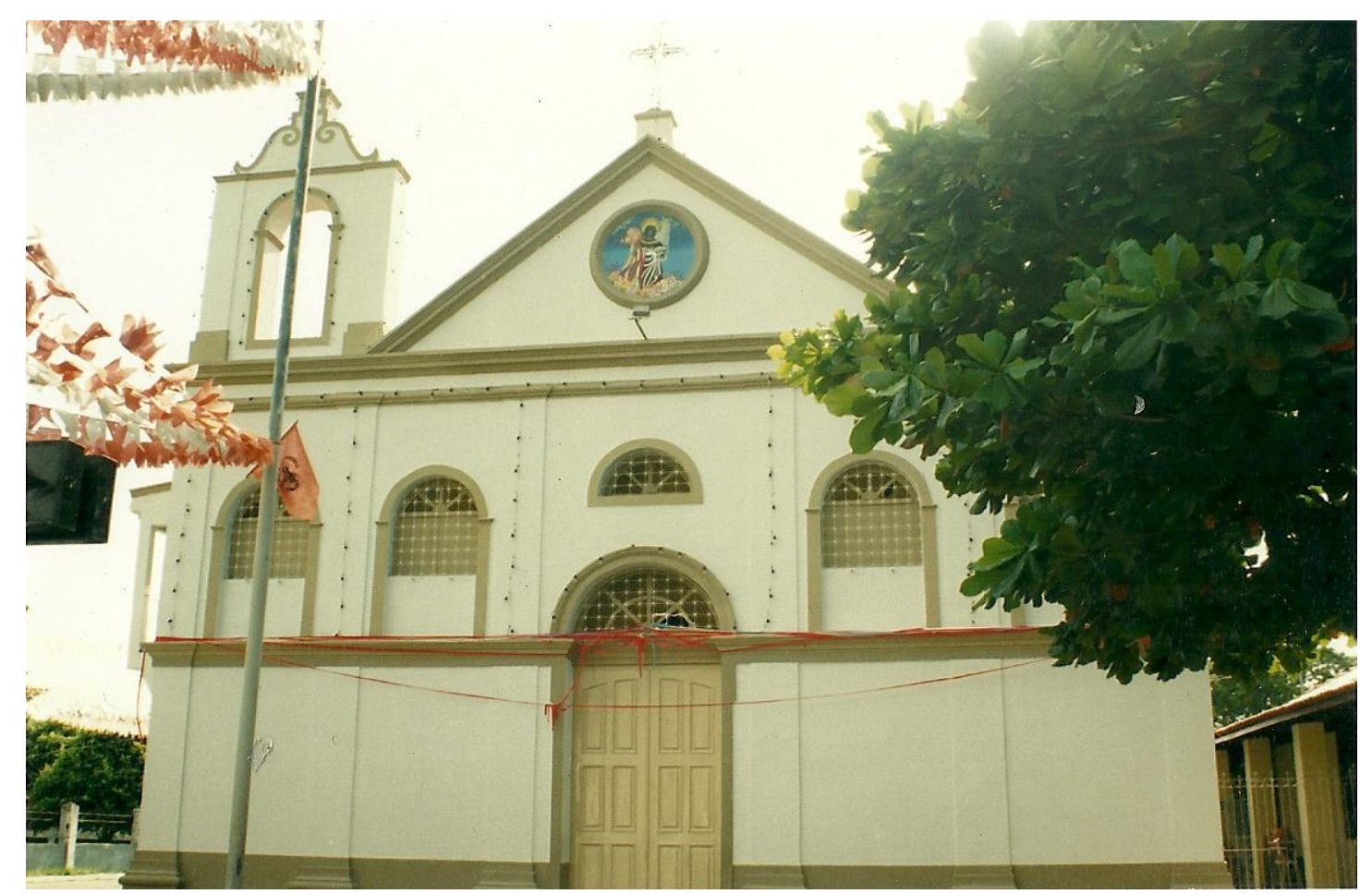

Imagem 6 - Igreja de São Benedito

Foto: Elis Miranda (2004)

\section{Considerações finais}

Esse texto foi desenvolvido como um exercício para pensar relacionalmente (BOURDIEU, 1989) a paisagem de Cametá. Foram destacados alguns elementos passíveis de análise e interpretação, relacionando paisagem como representação. Ressaltamos que além destes objetos selecionados outros poderiam ter sido destacados, o que mostra que a análise não se esgota nesse trabalho e que toda pesquisa é também um conjunto de escolhas que tem relação com os objetivos traçados, podendo, dessa maneira, outro ensaio ser elaborado.

A presença dos judeus em Cametá é reconhecida em inúmeros estudos sobre os judeus na Amazônia, e destacar elementos da cultura hebraica, por exemplo, mereceria um estudo mais aprofundado, o que não foi possível realizar nesse momento, mas se pode, em outro trabalho, identificar elementos hebraicos que ainda resistem na paisagem cametaense.

Outros elementos, como a presença e a ação da maçonaria em Cametá merece ser estudada. Essa afirmação justifica-se pela curiosa presença de símbolo maçônico na fachada de uma das igrejas erguidas em Cametá, investigando a relação existente entre maçonaria e a Igreja católica.

Por fim, ressaltamos a importância da realização de um trabalho dessa natureza como contribuição aos estudos de história da 
cidade e do urbanismo, pois mostra como, por meio de objetos impressos na paisagem, o poder e a dominação podem ser exercidos de formas sutis, como a instalação de uma estátua, a construção de um prédio, a instalação de um monumento artístico em

\section{NOTAS}

*Doutora em Planejamento Urbano e Regional. - Professora do Departamento de Geografia de Campos da Universidade Federal Fluminense e Colaboradora do Curso de Mestrado em Planejamento Regional e Gestão de Cidades, da Universidade Candido Mendes. Bolsista do Programa Observatório da Educação no Brasil - CAPES

**Doutorado em Sociologia pela Universidade de São Paulo. Professor do Instituto de Pesquisa e Planejamento Urbano e Regional (IPPUR) da Universidade Federal do Rio de Janeiro. Bolsista de Produtividade em Pesquisa do CNPq - Nível 1B.

${ }^{1}$ As fotos foram feitas pelas autoras em trabalhos de campo realizados nos anos de 2004 e 2005, no trecho entre para Belém e Cametá.

${ }^{2}$ Carta de Doação à Francisco Coelho de Carvalho. Chancelaria de D. Felippe III. Doações Livro 35, fólios 95-101. Torre do Tombo.

${ }^{3}$ Antônio José Landi, como ficou conhecido em Portugal e no Brasil, ou Guiuseppe Antonio Landi, como foi preferencialmente designado na Itália, onde nasceu (MENDONÇA, 2003, p. 19).

\section{REFERÊNCIAS} BIBLIOGRÁFICAS

ABREU, M. A. Sobre a memória das cidades. Revista Território, Rio de Janeiro, LAGET/UFRJ, v.4, n. 1, p. 4-26, jan./jun. 1998.

ARAÚJO, R. M. As cidades da Amazônia no século XVIII: Belém, Macapá e Mazagão. Porto: FAUP, 1998

BERQUE, A. Paisagem-marca, paisagem-matriz: elementos da problemática para uma geografia cultural. IN: CORRÊA, R.L. E ROSENDAHL, Z. Paisagem, tempo e cultura. Rio de Janeiro: EdUERJ, 1998. p. 84-91

BOURDIEU, P. O poder simbólico. Rio de Janeiro: Bertrand, 1989.

CORRÊA, R. L. A Geografia cultural e o urbano. IN: CORRÊA, R. L. ROSENDAHL, Z. (Orgs). Introdução à geografia cultural. Rio de Janeiro: Bertrand Brasil, 2003. p. 167-186.

COSGROVE, D. A geografia está em toda parte: cultura e simbolismo nas paisagens humanas. IN: CORRÊA, Roberto L.; comemoração a uma data importante para a história da cidade. Nesse sentido, planejadores urbanos devem estar atentos para o uso desses mecanismos de exercício de dominação.

ROSENDAHL, Zeny. (Orgs.). Paisagem, tempo e cultura. Rio de Janeiro: EdUERJ, 1998. p. 92-123.

COSGROVE, D.; JACKSON, P. Novos Rumos da Geografia Cultural. IN: CORRÊA, R. L. ROSENDAHL, Z. (Orgs). Geografia cultural: um século (2). Rio de Janeiro: EdUERJ, 2000. p. $135-146$.

DUNCAN, J. The city as text: the politics of landscape interpretation in the Kandyan Kingdom. Cambridge: Cambridge University Press, 1990

DURKHEIM, E. Formas elementares da vida religiosa. São Paulo: Abril Cultural, 1978.

GEERTZ, C. A interpretação das culturas. Rio de Janeiro: Livros Técnicos e Científicos, 1989.

LOWENTHAL, D. Past Time, present place: landscape and memory. The Geographical Review, New York, V. LXV, n. 1, p. 1-36, jan. 1975. p. 1-36).

MACHADO, L. O. Mitos e realidades da Amazônia brasileira: contexto geopolítico internacional $(1540-1912)$. Tese (Doutorado em Geografia) - Facultat de Geografia e Historia, Universitat de Barcelona, Barcelona, 1989.

MAXWELL, K. Marquês de Pombal: paradoxo do iluminismo Rio de Janeiro: Paz e Terra, 1996.

MENDONÇA, M. C. A Amazônia na era pombalina: correspondência inédita do governador e capitão-general do Estado do Pará e Maranhão Francisco Xavier de Mendonça Furtado (1751-1759). Rio de Janeiro: IHGB, 1963.

MENDONÇA, I. M. G. António José Landi (1713/1791): um artista entre dois continentes. Lisboa: Fundação Calouste Gulbenkian, 2003.

MITCHELL, Don. Não existe aquilo que chamamos de cultura: para uma reconceitualização da ideia de cultura em geografia. Espaço e Cultura - Edição Comemorativa (1993-2008). Rio de Janeiro. UERJ, NEPEC, DEZ, 1996 (pp.81-101).

SALDANHA, A. V. As capitanias do Brasil: antecedentes, desenvolvimento e extinção de um fenômeno atlântico. Lisboa: Comissão nacional para as Comemorações dos Descobrimentos Portugueses, 2001.

SANTOS, P.F. Formação de cidades no Brasil colonial. Rio de Janeiro: EdUERJ, 2001

VITERBO, S. Dicionário histórico e documental dos arquitetos, engenheiros e construtores portugueses. Lisboa: Imprensa Nacional Casa da Moeda, 1922. 
PORTUGUESE REPRESENTATIONS IN THE AMAZON: IMAGES, LANDSCAPE AND PLACE NAMES

ABSTRACT : THIS STUDY ANALYZES THE PORTUGUESE REPRESENTATIONS IMPRESSED IN THE LANDSCAPE, PLACE NAMES, AND GEOGRAPHICAL OBJECTS IN THE AMAZON VALLEY, SPECIFICALLY THOSE LOCATED IN THE BRAZILIAN STATE OF PARÁ. THIS STUDY INTENDS TO IDENTIFY THE TEMPORALITY AND SOCIAL REFERENCES INHERENT IN THE GEOGRAPHICAL OBJECTS, AS WELL AS THEIR MEANINGS AND INTENTIONS. THE ANALYTICAL METHOD USED WAS BASED ON THE REGISTRY OF THE LANDSCAPE IMAGES THROUGH RECENT PHOTOGRAPHS. THESE IMAGES HIGHLIGHT ELEMENTS CONSIDERED SIGNIFICANT FOR THE STUDIES ABOUT SPATIAL REPRESENTATIONS. THE OBJECTS ANALYZED ARE RELATED TO: A) CULTURAL REFERENCES ABOUT THE AMAZONIAN RIVER TOWNS AND (IIIES, B) TOPONYMY, AND C) THE HIDDEN MEANINGS CONTAINED IN THE BUSTS, AZULEJO TILE ART, AND BUILDING FRONT DESIGNS.

KEYWORDS: REPRESENTATIONS, AMAZON, IMAGES END LANDSCAPE.

REPRESENTACIÓN PORTUGUESAS EN LA AMAZONIA BRASILẼ̃A: PAISAJES, IMÁGENES, TOPÓNIMOS

RESUMEN: EL ESTUDIO ANALIZA LAS REPRESENTACIONES LUSAS IMPRESAS EN EL PAISAJE DE LA CIUDAD CAMETA EN EL ESTADO DE PARÁ. El ARTíCULO TIENE COMO OBJETIVO IDENTIFICAR LAS REFERENCIAS SOCIALES Y TEMPORALES DE LOS OBJETOS GEOGRÁFICOS, ASÍ COMO SUS SIGNIFICADOS E INTENCIONES. El ANálLIS SERÁ EN EL PANORAMA ACTUAL DE LA CIUDAD. LA FOTOGRAFÍA ES LA BASE DE REGISTRO. A TRAVÉS DE OCHO IMÁGENES QUE SE HIIIERON EN CAMETA EN LOS AÑOS 2004 Y 2005 SE DESTACAN ELEMENTOS CONSIDERADOS IMPORTANTES PARA EL ESTUDIO DE LAS REPRESENTACIONES. LOS OBJETOS DESTACADOS ESTÁN RELACIONADOS CON: A) LAS REFERENCIAS A LA CULTURA DE UN PUEBLO RIBEREÑO DEL AMAZONAS B) EL PERIODO DE POMBAL (1750-1777), C) DE LA HISTORIA, COMO EL MOVIMIENTO DE CABANAGEM (1835-1837), Y D) REEERENCIAS LUSAS.

PALABRAS CLAVE: REPRESENTACIONES, AMAZONIA, IMÁGENES, PAISAJE 